\title{
Landscape in Historical Urban Textures: "Walled City Nicosia From the Past To The Present"
}

\author{
By M.A. Esra Köksaldı, Assoc. Prof. Dr. Zihni Turkan*, \\ Assoc. Prof. Dr. Buket Asilsoy
}

\begin{abstract}
Historical urban textures are the whole of the open and closed public spaces with the buildings and transportation axis, shaped by the cultural heritages of cities. One of the most important elements in historical urban textures, bringing dwellers with nature, and giving life to the city, are landscape spaces. The capital of Cyprus, Nicosia, also has a very rich historical texture. Within this context, the aim of this study is to examine the landscape of the historical urban texture of Nicosia from the past to the present, within the whole of various cultural periods including the present day status. Therefore, the development of Nicosia through the historical process is given right after the introduction. After the introduction, landscape of walled city of Nicosia was examined through the historical periods: Lusignan Period, Venetian Period, Ottoman Period, British Period, Republic of Cyprus Period, and the present day period, TRNC Period.
\end{abstract}

Keywords: Historical texture, Urban landscape, Walled city, Nicosia, Cyprus

\section{Introduction}

In the last decades urban sustainability has been highly acknowledged as the world is experiencing significant challenges (James, 2015; Oktay, 2004). And cultural sustainability is an emerging dimension of this key concept, beside social, environmental and economic dimensions (Soini \& Birkeland, 2014). Historical textures are very significant for cultural sustainability of the cities in particular. In other words, historic urban quarters have a remarkable place in the cultural and historical heritage of any country (Doratli et al., 2004).

Historical urban textures are the sum total of buildings, transportation aisles, and open and closed public spaces shaped by the heritages of works belonging to different cultures in their histories developed through the processes since their first foundations. Forming the city centers in general, historical textures reflect their history to visitors in the form of open air museums at present. In addition, historical textures have a remarkable potential to strengthen the identity of the urban environments (Tiesdell et al., 1996).

Bringing citizens together with nature and giving life to the city, one of the most important elements of historical urban textures are the landscape spaces. Especially parks, groves, spaces, and trees and plants in streets, where residents meet, make up an important factor for sustainability of the historical urban textures with their physical, as well as sociological and psychological benefits for the citizens.

\footnotetext{
| ${ }^{1}$ Near East University, Graduate School of Applied Science, North Cyprus. 
The capital city of Cyprus, Nicosia, has always been the administrative center of the island with its two and a half thousand years of past, since its foundation, and has a very rich historical texture with the cultural heritages of various civilizations. The historical city center of Nicosia, surrounded by walls has a historical mosaic made up of architectural works beginning with the Lusignan period (1191-1489), the Venetian period (1489-1570), the Ottoman period (1571-1878), and the British period (1878-1960), and with constructions of the recent past. With the advantage of one arm of the Kanlidere (Pedios River) running through the walled city in the past, the city gained a rather rich landscape. The aim of this study is to examine the landscape of the historical city texture of Nicosia from the past to the present, through its formation and development during different cultural periods with its positive and negative aspects including the present day situation. The fact that no such research has been carried out on this topic makes this study important, and it is hoped that it will shed light on further studies on the landscape of historical city texture of Nicosia, and form a resource.

In this study, literature review was carried out using the qualitative research method, finding information, documents, and visuals related to the historical city texture of Nicosia. Field study was carried out by on-sight observations, examinations, and photography in order to display the situation of the historic quarter until today.

\section{History Of Nicosia}

The capital of Cyprus, Nicosia, takes place in the center of the island known as the Mesaoria Plain. Although it is not known precisely when the city was founded, excavations revealed Bronze Age relics, showing that Nicosia has a very old history (Gunnis, 1973; Gürkan, 2006).

Before the foundation of Nicosia, the antique city of Ledra existed in the south-west of the current city, in the VII Century B.C. Destroyed by Arab raids, the city was re-built by Levkon, son of the Egyptian King Ptolemy I, where the present Nicosia is, in 280 B.C. It was named Levkontheon, thus Nicosia took its place in history (Anonymous, 1978; Turkan, 2008). Nicosia preserved its importance in Cyprus during the Roman (50 BC-395 AD) and Byzantine (395-1191 AD) periods, and thrived to become an important administrative and business center of the island (Altan, 2006).

The Lusignans bought the island from King Richard I of England for a hundred thousand gold, in 1191, and they made Nicosia the center of their sovereignty on the island (Lukach \& Jardine, 2007). The Lusignans spent a part of the islands revenues on developing Nicosia. They built $7500 \mathrm{~m}$. long walls around the city, fortified with towers, and having five gates with drawbridges. Churches and a cathedral, forming the historical texture of the walled city today, still survive as important architectural works of the period (Gürkan, 1989).

During the Venetian period, which started in 1489, Nicosia was chosen as the capital again. The Venetians did not invest in the city, but they knocked down numerous Lusignan buildings and the walls, thus making the city smaller. In order to make it easier to defend the city, they built city walls with three gates, 4800m in circumference (Balkan, 1998; Gürkan, 1996). 
Nicosia continued being the capital city during the Ottoman period, which started in 1571. The Ottomans contributed to the city with architectural works, such as inns, baths, mosques, fountains, and houses, thus helping the city thrive socially and business wise. Turkish architectural works of this period have a very important place today within the historical city texture of Nicosia (Anonymous, 1982; Bağışkan, 2005; Salvator, 2012).

During the British period, which began in 1878 with the island being leased to Britain, Nicosia became the capital city (Metin, 1959). With the economic prosperity brought by the British, the city developed and spread outside the walls (Hikmetağalar, 1996). The administrative buildings and houses constructed in the city added a new architectural style to the historical city texture. The increase of overseas interactions resulted in Nicosia being recognized. The first census carried out in Cyprus in 1881, established the population of the city as 11531 (Gürkan, 2006).

In 1960, the Republic of Cyprus was established, based on the partnership of Turkish and Greek communities, and Nicosia became the capital of the new republic. Thus, the city became an important center in the Middle East, and a transit point. Multi-storey buildings, constructed with contemporary materials and with a modern architectural style, created a contradiction with the historical texture of the walled city.

As a result of political and armed conflicts that started between the Turkish and Greek communities at the end of 1963, Nicosia was divided into two, as north and south. The city center within the walls, housing the historical city texture was also partitioned and parts of the historical texture on the border area were harmed.

After the war in Cyprus in 1974, and the following political changes, the island was divided into two administrations in the north and in the south. Nicosia was also divided as north and south; continuing its development as the capital of the TRNC in the north, and the capital of the Republic of Cyprus in the south. Besides being the administrative, business, and social center of the island, the city at present is an important center in the Middle East with its higher education institutions and its population of well over 300,000 (approximately 100,000+ in the north and 200,000+ in the south), (Figure 1). 


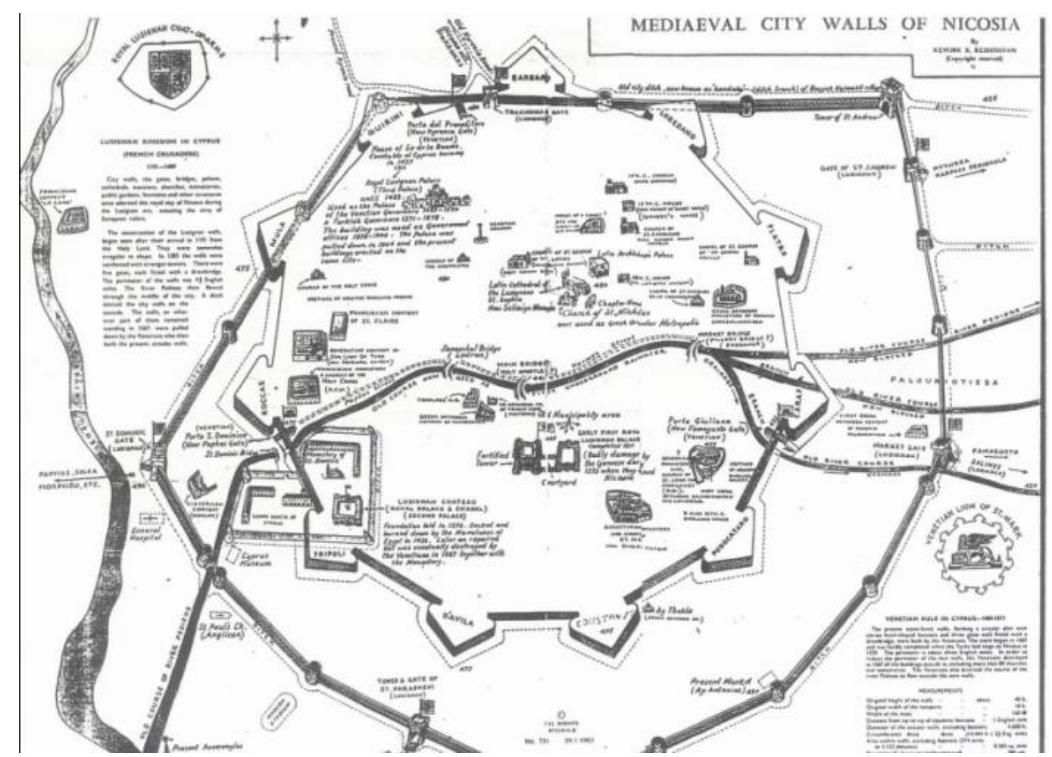

Figure 1- Nicosia City Walls of Lusignan (1191-1489) and Venetian (1489-.....)

(K. K. Keshishian - Mediaval City Walls of Nicosia, 1959)

\section{Landscape Of Historical Texture Of Nicosia Walled City From Past Up To Today}

The walled city texture of Nicosia, which was formed and developed with the rich architectural heritage of various cultural periods of the island during its two thousand five hundred years history, aroused with its landscape in public and private spaces. The landscape of the walled city of Nicosia can be examined through the periods of its history chronologically as below.

\subsection{Lusignan Period (1191-1489)}

When the Lusignans chose Nicosia as the capital of Cyprus, they constructed the five-gate city walls, encompassing a wider area than the present walls; adding monasteries around, and churches, cathedrals, and large mansions inside. These constructions, resulting in an increase in the population of the city, also brought a formation of wide streets, neighborhoods, and open spaces as well (Gürkan, 1996), (Figure 2). 


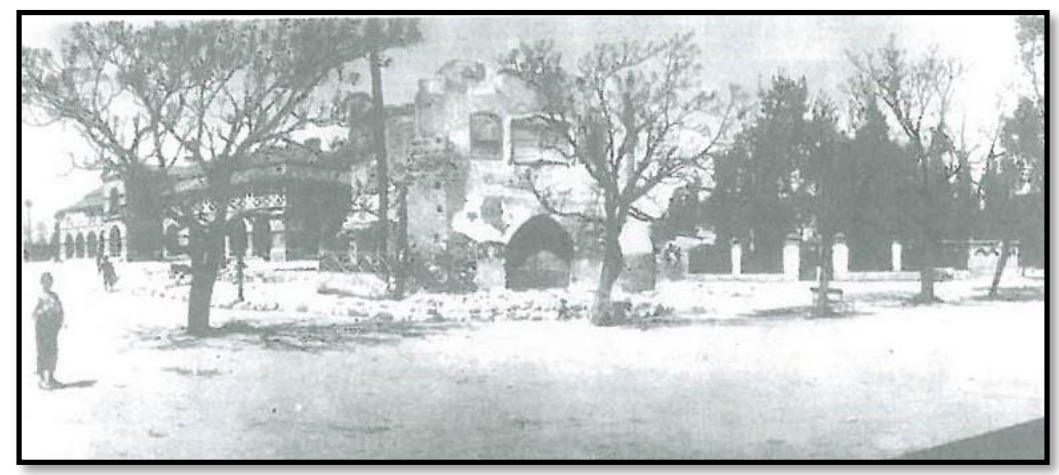

Figure 2- Lusignan Palace and Sarayonu Square (Z. Turkan - 2008)

Information is obtained from sources that besides the development of constructions in Nicosia during the Lusignan period, there were large vegetable gardens, orchards, and green spaces of plants as well (Gürkan, 2006). During the 300 year Lusignan period, open and green spaces had a development at the same rate with the increasing number of new buildings (Gürkan, 1996). Besides the green spaces in the city, elaborate landscape planning was implemented in the yards of monasteries, churches, mansions, and palaces. This shows that the Lusignans gave as much importance to green spaces as they gave to the buildings they constructed with a great pride and grandeur. The green spaces prevailing the city drew the attention of visitors and resulted in referring to those spaces in their memoirs with admiration. The Italian notary, Nicolai Martoni, who visited the island in 1394, described Nicosia as follows (Cobham, 2013; Y1ld1z, 1994):

"(...) In this Nicosia city there are monasteries dedicated to St. Francis, St. Dominic, and St. Augustine, and places of visit, which are all large and beautiful, and they all have two inner gardens, one large and one small, where oranges and other fruits are grown. There are gardens and orchards in the city besides fields for growing vegetables, barley, and wheat. Indeed I saw a field bigger than 30 modia near the St. Augustine Monastery within the city walls, planted with barley and wheat. Similarly, I saw cabbage and various other vegetables planted in the gardens of St. Theodor, which is a nun's church. These gardens were the size of 20 modia."

The Cypriot Dominican priest, Etienne de Lusignan, who was a descendant of the Lusignan kings, described the city of Nicosia in his book "Chorografia", printed in Italy in 1573 like this (Cobham, 2013):

"(...) The weather is perfect, water is sweet, and the soil itself is full of fruit and vegetable gardens in a nice way. (...) This city was once a large place with a circumference of 3 leagues or 9 miles. True, it was not completely inhabited, but it had numerous gardens. Large gardens. (...) Outside the city. From the lower gate to the St. Dominic gate all the land was full of gardens which stretched a league. Water was so plenty and was drawn from wells with a type of large water wheels, like in Famagusta."

Another important factor for the development of green spaces in Nicosia during this period was that a branch of the Pedios River used to run through the city center. It is known that open and green spaces were created around the river which was in a central position. In the itinerary of the Italian notary Nicolai Martoni, about Nicosia, who visited the island in 1394, the river was mentioned as below (Severis and Şevketoğlu, 2003): 
"(...)I think Nicosia is bigger than Aversa, and there is a river running through it, and when it does not rain, one can cross across by stepping on stones. A lot of water runs in the river when its rainy, so there are a few bridges across the river some of which are made of stone and some from wood. During rain, people use these bridges."

Having considerable amount of open and green spaces besides the architectural constructions in the city shows that Nicosia was a green city during the Lusignan period.

\subsection{Venetian Period (1489-1571)}

Nicosia continued its existence as the capital city during the Venetian period as well. In order to enable a more effective defense of the city against threats from outside, the Venetians downsized the city by building the present city walls, which are $5 \mathrm{~km}$ in circumference. These walls comprise eleven bastions and three gates (Paphos Gate, Kyrenia Gate, and Famagusta Gate) (Gürkan, 1996). The Venetians knocked down many building of the Lusignan period and use their stones for building the city walls. The downsizing and destruction that Nicosia suffered in this period resulted in a lot of problems in the development of the city. It is understood that the open and green spaces created during the Lusignan period did not show sufficient improvement for the development of the city (Fig. 3).

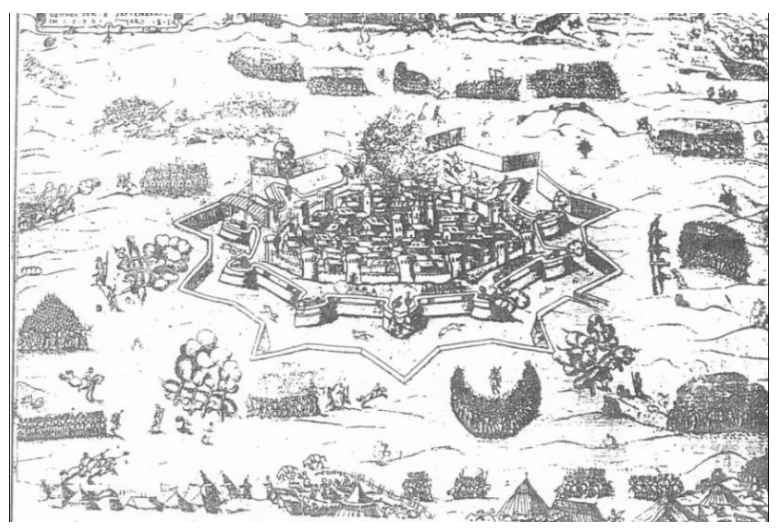

Figure 3- Ottoman Blockade of Nicosia (1570) (Department Office of Map)

Examining Nicosia from the perspective of landscape planning during the Venetian period, it can be seen that green spaces were formed inside the yards of buildings, and as fruit and vegetable gardens in some areas. During this period the Venetians not only demolished some buildings in order to shrink the city, but they cut down many trees as well, and also changed the river bed by taking it outside the city walls (Gürkan, 2006). Cypriot historian Etienne de Lusignan describes the destruction in the city by demolishing buildings and cutting trees as follows (Cobham, 2013):

"(.....) In the same way, the Venetians destroyed the Royal Monastery as well. They also destroyed two inner gardens of this monastery, which were full of orange trees and were laid with beautiful marble. (....) The river used to run through the city. It used to go in from one side and out of the other side. In 1567, while fortifying the city, they cut off the river from outside." 
Although the demolishing during the Venetian period damaged the city at an extensive scale, Nicosia managed to preserve its green city image due to the water resources and fertile land to some degree. The French silk merchant, Jacques le Saige, who came to Cyprus in 1518, described in his itinerary the yards of the monasteries, the green spaces around them, the fruit and vegetable gardens, and the amount of water as follows (Cobham, 2013):

"There is a large garden next to the monasteries irrigated from a well. A horse draws a large water wheel, and a number of earthen cups attached to this wheel draws astounding amount of water from this well. Many narrow pipes are laid in the garden, which distribute the water. There were a lot of fruit trees, most of which were pomegranate, and under the trees, the garden was full of pumpkins, water melons, cucumbers, and other fine things. These fruits and vegetable would not grow if it were not for these wells. And it is astonishing that there are so many wells."

The English pilgrim, John Locke, who visited Cyprus in 1553, described the beauty that plants in Nicosia added to the island, and the green spaces and the number of wells inside the city (Cobham, 2013):

"On the sixth day of October we travelled to Nicosia, 7 Cyprus miles from Arnacho. This is the oldest city of the island and is surrounded by walls. (....) Not all parts of the city are inhabited, but there are many large gardens, date trees, pomegranate trees, and other fruit trees. All the counts and noble people of the island live here. All the counts and nobles of the island have a house here. There is a water source in the city belonging to the Venetian state, and gardens are irrigated with its water once every eight days. (....) Outside the city, the land stretching about 1 league, from the Lower Gate to St Dominic Gate, is covered with gardens. Water was abundant and was drawn from wells with water wheels, like in Famagusta." Although the Venetian period was an era of demolition and destruction for the historical city texture of Nicosia, the landscape planning in Nicosia survived to some extent by the preservation of the landscape from the previous period with the contribution of the geographic and climatic characteristics of the island.

\subsection{Ottoman Period (1571-1878)}

During the new period in Cyprus, with the sovereignty of the Ottomans in 1571, Nicosia preserved its status as capital (Pasha District). The Ottoman State constructed many new buildings in Nicosia in the Turkish architectural style, which were to play an important role in the development of the city (mosques, tekkes, inns, baths, fountains, houses), which catalyzed new social and economic developments. The existing wide streets, squares, and green spaces from the previous periods, underwent a change with the newly constructed buildings, becoming curvy axes and narrow streets, turning the city into a kind of labyrinth (Gürkan, 2006; Turkan, 2010; Turkan, 2018), (Figure 4). 


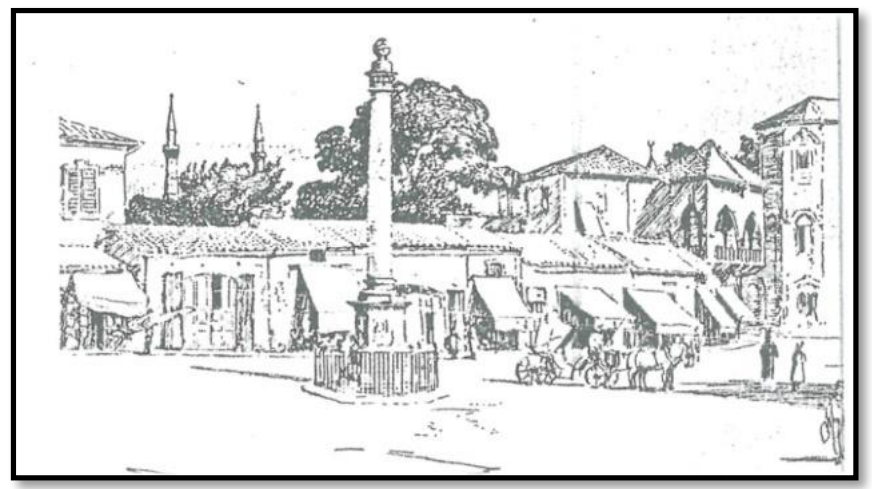

Figure 4- Sarayönü Square- End of 1800 (G. Home)

Nicosia landscape declined during the Ottoman period due to the fact that wide green spaces and gardens diminished compared to previous periods because of new constructions in the city. Despite this situation, Nicosia still preserved its importance in urban landscape and it was mentioned in the writings of travelers who visited the city during this period. French traveler Stockhove, who visited Nicosia in 1631, wrote that Nicosia was rich in gardens full of date trees (Cobham, 2013). Austrian Archduke Louis Salvator, who visited Cyprus in 1872 and stayed in Nicosia for a year, described the contribution of various plants to the landscape of Nicosia like this (Yektaoğlu, 2012):

"After passing through a serious of nice looking hills, founded on an empty plane, Nicosia appeared with its tall, thin date trees and minarets, and picturesque mountains far beyond. It was like a dream come true from the Thousand and One Tales. A bouquet of orange and date trees in a land devoid of green, an oasis surrounded by man-made walls..."

Almost all the houses in Nicosia during the Ottoman period had inner yards. The main causes of yard culture showing such a development and having an important place in the city were the climatic conditions of the region, abundant water sources, and the place of yards in Turkish life culture. Surrounded by high walls in order to decrease contact with street life and to create spaces of privacy, these yards became social open spaces for children to pass time, to live relationships with neighbors, and to carry out daily chores (Dağl1, 1999).

The yards, which had a place during the Ottoman period, were made up of various types of plants, water elements, and spaces for people to rest and carry out their daily chores. A traveler named W.M. Leake, who visited Nicosia in 1800, described the gardens of the city as such (Cobham, 2013):

"(.....) Flat roofed houses of a higher class, with their latticed windows and small balconies in gardens of orange and lemon trees, and the city walls gave Nicosia a respectable and picturesque look from a distance." An English traveler named Dr. Edward Daniel Clarke, who visited Cyprus in 1801, described in his memoirs the yard and fruit trees of the house in Nicosia, where he stayed (Cobham, 2013):

"The landlord showed us his beautiful garden: The garden was full of apricot trees with already ripened fruits. And again, as he told us, the wine we were to drink at dinner was cooled in a marble fountain under the shade of orange, citron, lemon, fig, pomegranate trees and vines." 
Louis Salvator, who visited the city in 1872, in his book about Nicosia described the plants and water wells in the gardens in the relative section as follows (Yektaoğlu, 2012):

"Almost every house has an orange garden. Here, gigantic date trees rise from among fruit trees. Besides these private gardens, there are wide public gardens within the boundaries of the city. These gardens make up more than half of the area of the city. All these gardens are surrounded by mud brick walls on the street side. The side of the garden facing the porch of the house has a low railing. Gardens are watered either from the well, or from water taken directly from sewers. All kinds of fruits are grown there. (....) The spaces next to fruit trees make up the beautiful vegetable gardens. These are watered by a type of wheel that brings up water and sprinkles it to a distance."

Dominating the island of Cyprus for about 308 years, the Ottomans built new buildings, inns, fountains, baths, mosques, madrasahs, and houses during this process in order to help the structural, social, and commercial development of Nicosia (Turkan, 2016). They developed extensively the craftsmanship and market culture which already existed in Nicosia from previous times, and they have been successful in both business and social sense. They brought the yard culture to Nicosia too - which had a great importance for Ottomans - and contributed to the landscape development of the city (Figure 5).
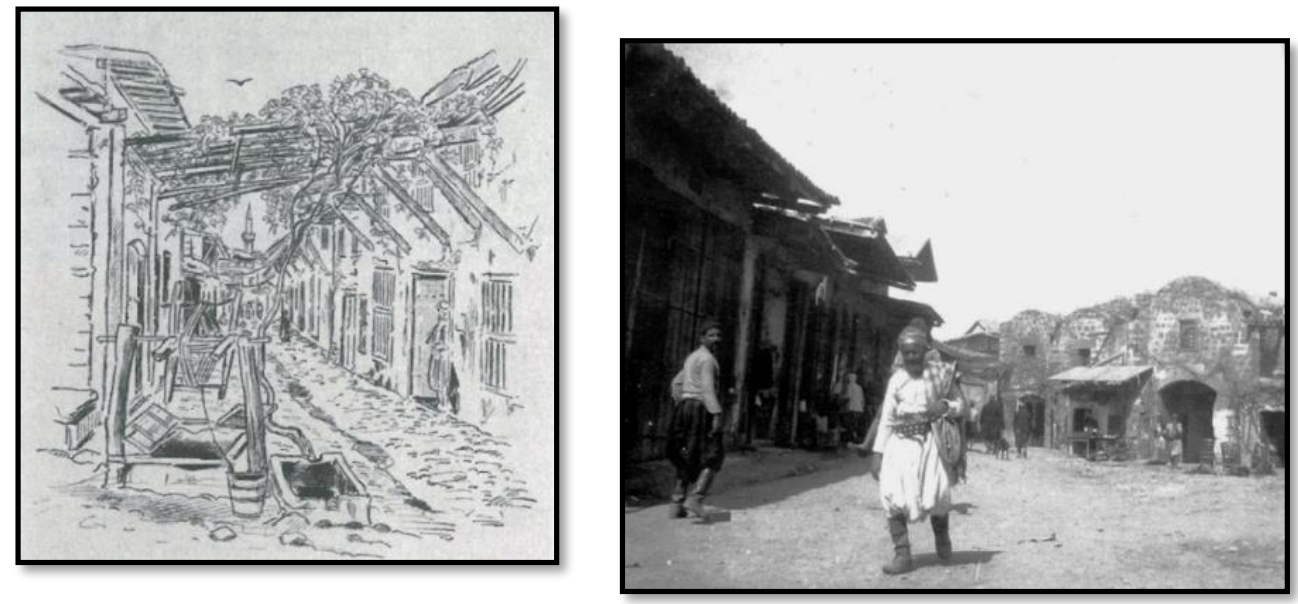

a) Arasta Bazaar - 1872 (Yektaoglu, 2012), b) Asmaaltı Bazaar- 1878 (From E. Eryener)

Figure 5- Ottoman Period Nicosia Bazaars

\subsection{British Period (1878-1960)}

During the British period, which began with the Ottomans leasing the island of Cyprus to the British in 1878, Nicosia continued its existence as the capital city. This period had been an era of change and prosperity for Nicosia. New buildings, hotels, shops, and inns were built, roads, streets, and squares were developed and re-shaped, and the population increased significantly. The English writer and researcher, W Hepworth Dixon, who visited Nicosia during the first months of the British domination of Cyprus, thought that Nicosia could be divided in four different sections, and named these as Konak Neighborhood, Mosque Neighborhood, Levantine Neighborhood, and Cathedral Neighborhood. 
While defining the neighborhoods, he considered the buildings, open and green spaces, and the population living there. This account of Dixon's gives quite a lot of information about the shape and state of the city at that time (Gürkan, 2006).

One of the important changes in the city during the British period is the change in the architectural style of the city. During the first years of their dominance the British continued the architectural style of the Ottoman period, but later they began using an architectural style known as the neo-colonial architecture. These changes affected exterior spaces as well; the roads were widened, and the yard culture of the city occupied an important place in life during this period (Dağl1, 1999). An English writer named W.H. Mallock, who visited the island in 1889, described the yards of the city and their relations with streets in his 1889 book "In an Enchanted Island" (Gürkan, 2006):

“(.....) We passed from one street to another. This was a narrower street. Then we passed into another, and another. Some of these were alleys stretching along high mud brick walls. The date trees and the green of fruit trees were visible over the walls."

A lot of writers and travelers visited the island starting with the British period, and all of them expressed their admiration of Nicosia in their memoirs. Many of those travelers compared Nicosia to Damascus because of the landscape the city possessed. The main reason for this comparison, according to them, was the fact that Nicosia, in the middle of a barren plane away from green, had a green appearance with plenty of trees (Gürkan, 2006), (Figure 6).
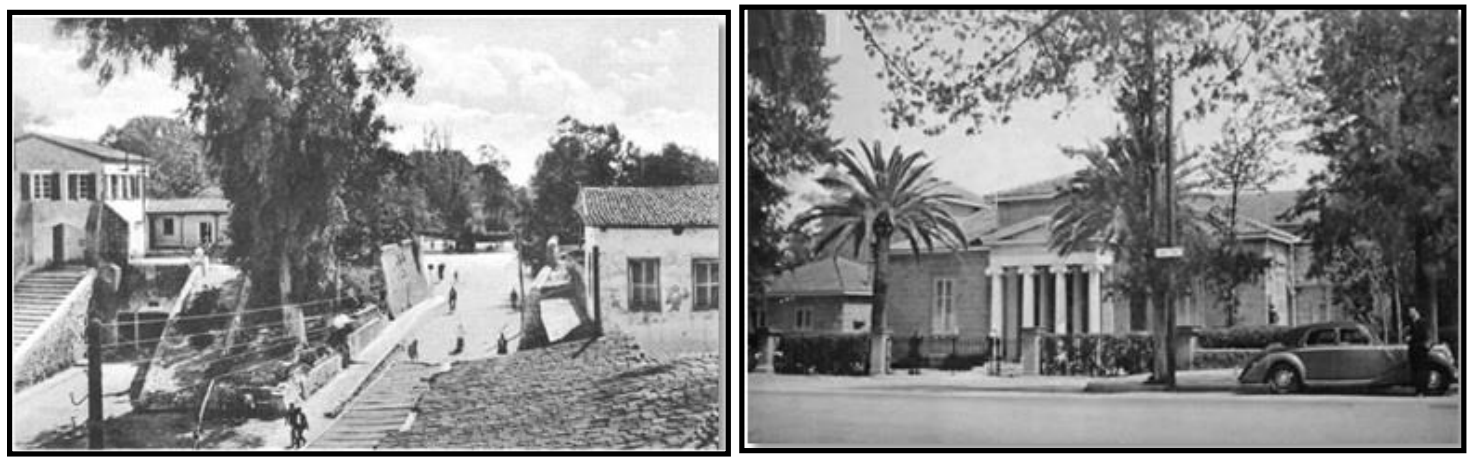

a) City Landscape- 1940 (From E: Eryener), b) City Landscape- 1957 (From E. Eryener)

Figure 6- Nicosia's Landscape in British Period

W. Hepworth Dixon, who visited Nicosia in 1878, described his observations and memories about the city in his book "British Cyprus", published in 1879. In his book he talked about the landscape of the city, and described the different types of trees in Nicosia and the beauty they added to the city (Gürkan, 2006):

"The mosques and trees of the city were visible from where we stood. A low city wall was stretching to the left and right with their bastions ahead of us. (....) Minarets, bell towers, and trees rose above the walls and the gate. (....) trees of various darkness, from cypress to orange, fig, and date were visible."

According to the Kitchener landscape map of Nicosia, dated 1881, it is understood that the city was quite rich in green spaces. During this period, green spaces in Nicosia took 
place in squares, streets, yards of mosques, and in the gardens of almost all the houses. If the map is examined in detail, it is seen that the number of plants in abundance in certain parts of the city resulted in Nicosia displaying a forest like view (Figure 7).

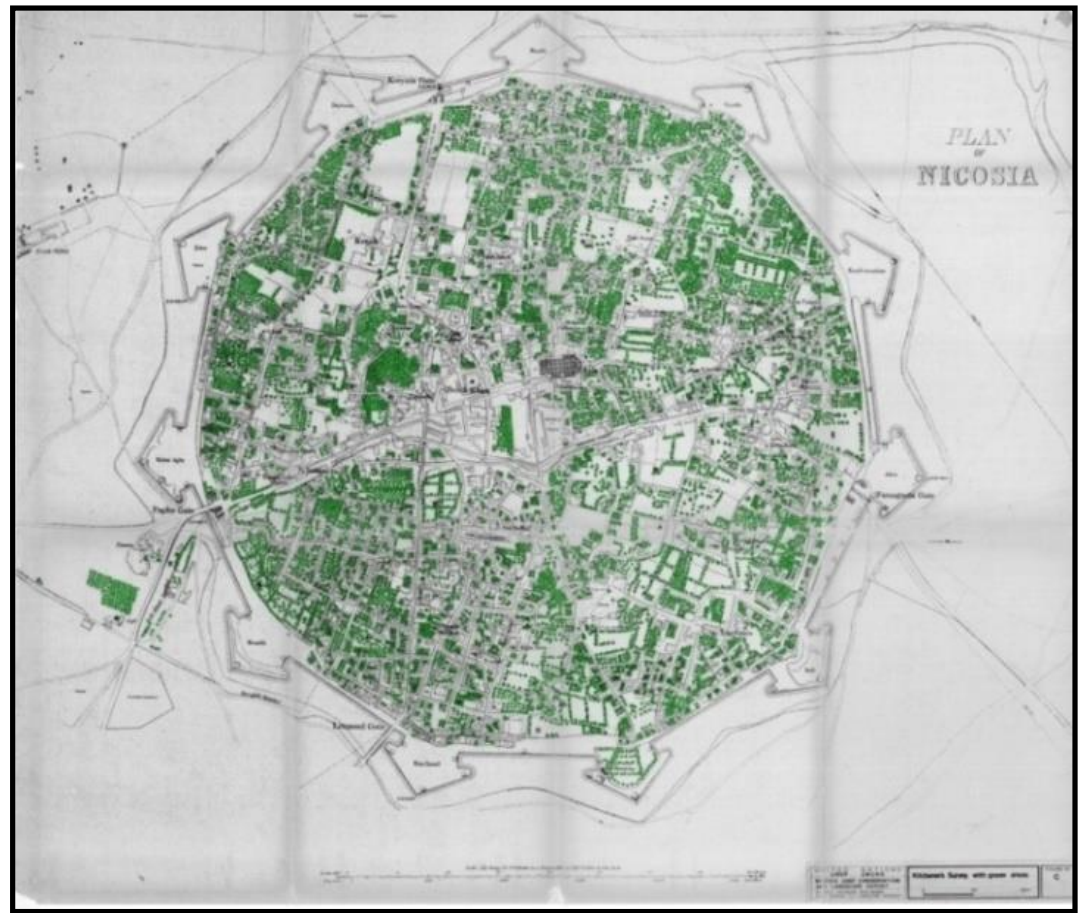

Figure 7- Kitchener Landscape Map of Nicosia - 1881 (From Town Planning Department of T.R.N.C.)

The sovereignty of the English lasted until 1960, and during this period important developments took place in Nicosia in business, social, and cultural life. Many buildings of this period, which has an important place in the creation and development of the historical city texture, have survived to the present. It is also understood from the visitors who visited the city during this period, and from sources, that the landscape of the city also achieved quite a lot of development.

\subsection{Cyprus Republic Period and After (1960-1983)}

Nicosia preserved its status as the capital city in the Republic of Cyprus, which was established in 1960. The status of the city as the administrative center enabled the fast development of the commercial, social and cultural functions in the city.

As the capital city of the new republic, Nicosia gained a quality as an important transit center in the Middle East. During this period a lot of historical buildings and houses were demolished and concrete multi-storey buildings were constructed in their places. With the demolishing of buildings, their gardens were also damaged. The structural changes of the period also affected the change of squares, roads, and streets. In 1964 Nicosia was divided as north and south with a green line as a result of political conflicts between the Turkish and Greek Cypriot communities. This division became a period of stagnation in the 
development and growth of Nicosia. The old characteristic structure that the city possessed underwent a change and decay. A large number of people leaving their abode resulted in demographic changes.

During this period, landscape planning in the northern half of Nicosia could not preserve the importance it possessed in previous years, and it suffered damages and disappeared to a great extent because of the unfavorable situations right after the Republic of Cyprus period. Moreover, as the houses within the historical texture were demolished, the large vegetable and fruit gardens in the texture disappeared, many plants in the streets and squares were cut down (Figure 8).

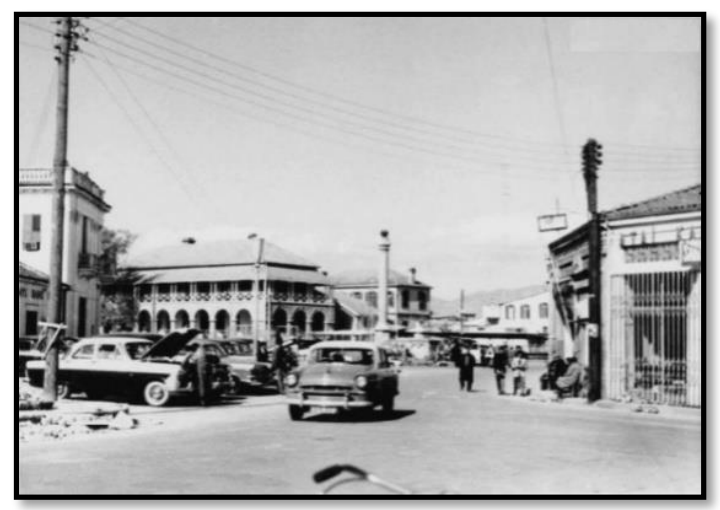

Figure 8-Sarayonu Square- 1960 (From E. Eryener)

The inter-communal conflicts since 1964, and the separation of Turkish and Greek communities in Cyprus, brought many problems and unfavorable situations. One of these problems was the difficulties in circulation and transportation, and the lack of recreation areas for the people living in the Turkish part of Nicosia for meeting, gathering, and fulfilling their social needs. With the aim to meet such needs parks were created within the moats of the historical texture of Nicosia. The first of such parks is the Çağlayan Children's Park between the Musalla Bastion and Cevizler Bastion. The other two are Mücahitler Park and Kuğulu Park, on the east and west of the Kyrenia Gate.

According to information gathered from Nicosians, Kuğulu Park (Swan Park), which took its name from the swans in its ponds, became a social gathering space for Nicosians, with its landscape design, plant elements, and musical events held there. The changes in the north of Cyprus after 1974, resulted in this park losing its importance.

Mücahitler Park, in the east of the Kyrenia Gate, had an important place in the social life of Nicosia with its well-kept landscape and various social activities held in it. Having elements of play and recreation for children, and having a wider landscape compared to other parks, Çağlayan Children's Park has been an important city park in which Nicosians spend time with their children (Figure 9). 

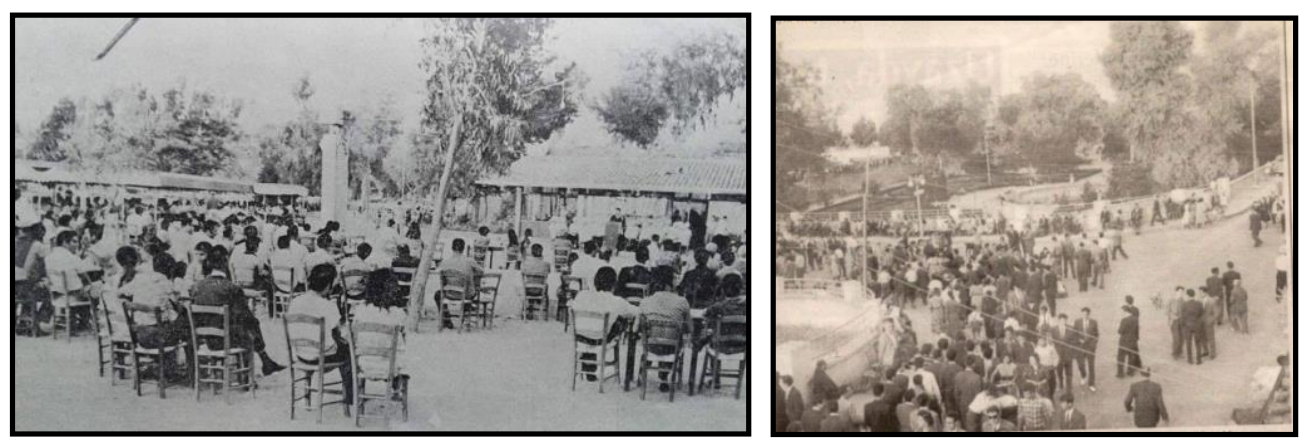

a) Mucabitler Park - 1971 (Ozaltm, 2018), b) Caglayan Park - 1965 (From S. Olgun) Figure 9- Cyprus Republic Period City Parks

The changes lived during and after the Republic of Cyprus period caused a depreciation of the historical texture of Nicosia and resulted in its demolition and destruction to a great extent. The Republic of Cyprus period has been an era during which the historical texture was not protected, deterioration was seen, and the traditional life style and social, cultural life changed into another dimension.

\subsection{Turkish Republic of Northern Cyprus Period (1983- ... )}

Nicosia preserved its status as the capital city during the new period that began with the founding of the Turkish Republic of Northern Cyprus (TRNC), which was established after a change of administrative system in North Cyprus in 1983. In this period the changes in the demographic structure and traditional lifestyle that began inside the walled city which houses the historical texture of Nicosia, continued increasingly, and resulted in grave damages in the historical texture due to unsuitable functions and renovations in buildings. These deteriorations in the historical texture of northern Nicosia, and other problems, negatively affected the texture as a whole and resulted in the open green public spaces and private green spaces to annihilation.

The landscape planning of walled city of north Nicosia started deteriorating fast with the first years of the TRNC, and in time many of the green spaces disappeared. It is possible to define the present status of the historical texture of the north of Nicosia as a dry city devoid of green; however it was once mentioned with admiration by visitors in the past as the largest green city of Cyprus. Increase in constructions within the walled city, and lack of sufficient conservation, caused the green spaces to be harmed, and many plants were either cut down or dried up. At present, the need for green in public spaces without landscape is met with plants growing in pots (Figure 10). 

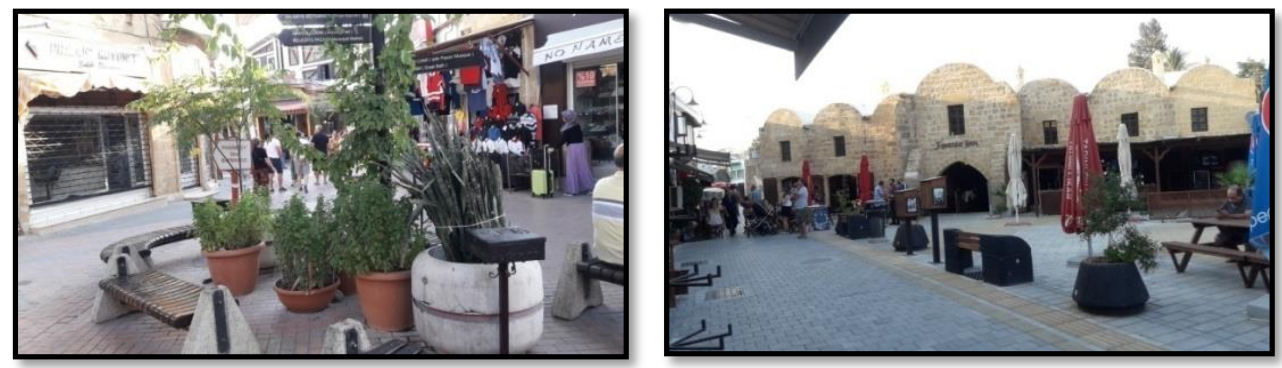

a)Arasta Square (E. Koksald - 2019), b) Asmaaltı Square (E. Koksald - 2019)

Figure 10-Landscape Planning in the Nicosia Historical City Texture

Another area where landscape planning was seen in the historical texture in past periods was the courtyards of houses, which people living there designed with care and looked after. The landscape of such house yards in the texture are almost all deteriorated at present. The main reasons for courtyards losing their importance is the fact that people living in those houses are far from the traditional culture of the historical texture, and not showing enough care to these spaces. These yards, having large surfaces, were changed by users' spatial additions, thus their functions were changed and landscape diminished. Another important cause for deteriorations is the fact that landscape was not sufficiently added to plans for the protection of the historical texture. The yards of religious and administrative buildings in the walled city are rather protected and did not suffer much deterioration. However, not enough care was shown to develop and renew these spaces (Figure 11).
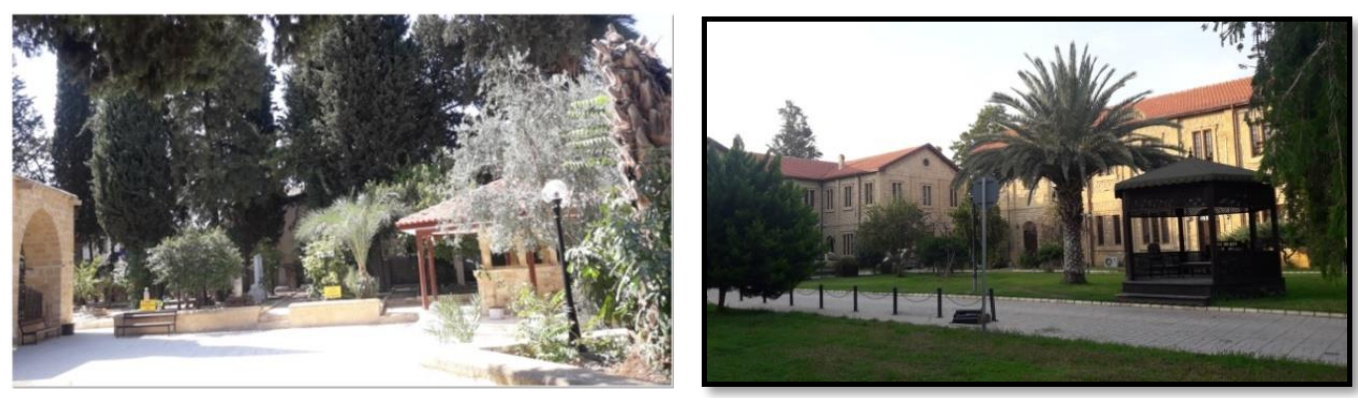

a) Garden of Arabahmet Mosque (E. Koksald - 2019), b) Garden of Tourism and Environment Ministry (E. Koksaldr - 2019)

Figure 11- Building's Gardens of Nicosia Historical City Texture

The only green space inside the historical texture is the Yiğitler Bastion Park on the Yiğitler Bastion, which is under the responsibility of the Nicosia Turkish Municipality. This park being right next to the green line which divides the city, and being a first degree military area, restricts its usage and does not meet the basic need of the people living there for a green space sufficiently. The trees in the park, which is open for public use during certain hours of the day, reflect the historical identity of the city. The plants in this place did not suffer much harm because of the position of the space. There is a kiosk in the park and some children's play elements. The children's play elements are rather old and uncared for 
at present, the cover materials in paths are worn out and in a bad state. Moreover, urban furniture in the park, such as the banks, lighting elements, and litter boxes are inadequate in numbers and worn out (Figure 12)
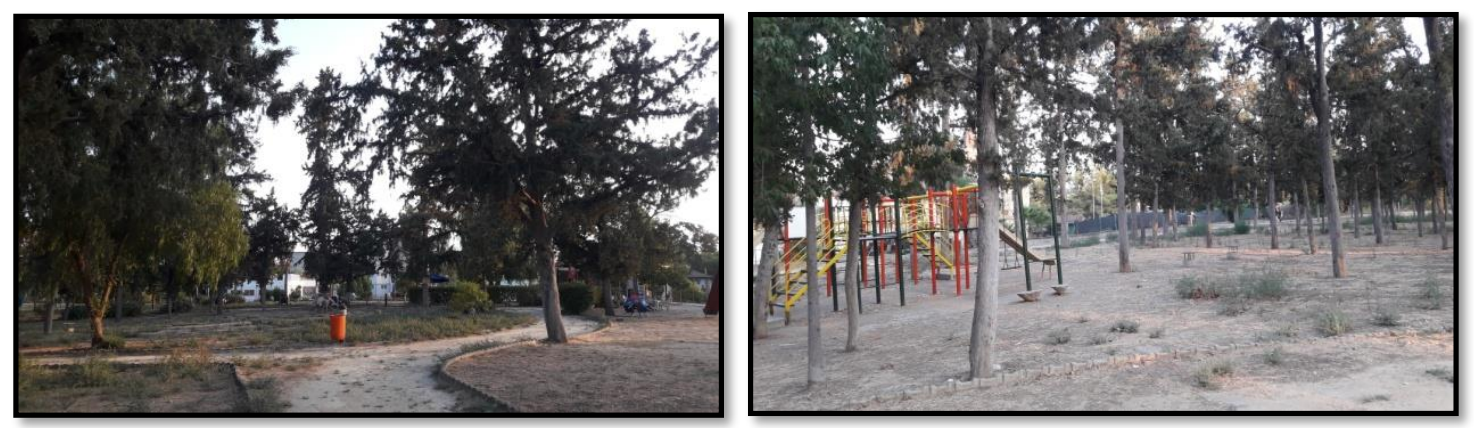

a) Landscape of Yigitler Bastion Park (E. Koksaldr - 2019), b) Yigitler Bastion Park Children Play Elements(E. Koksaldr - 2019)

Figure 12- Yigitler Bastion Park.

Located in the moat on the northern side of the city walls surrounding the historical city texture of Nicosia, and being the most active meeting spaces between 1963 and 1974, Kuğulu Park, Mücahitler Park, and Çağlayan Park have lost their city park functions to a great extent. At present, there is a cafeteria, children's game equipment, litter box, lighting, urban furniture such as banks, and a pond filled with earth within the Kuğulu Park on the west of the Kyrenia Gate. From the shape and size of plants in the park, it can be understood that they were planted in the past. At present, the park is used as a passing space for pedestrians, and sometimes used as a gathering space for various activities.

The Mücahitler Park on the east of the Kyrenia Gate has also lost its function as a park and is quite neglected. Again, used as a pedestrian passing space for the area, and sometimes used as a car park, there is a cafeteria, some kiosks, and a newly built ornamental pond in this park. The plants inside are from the past.

In Çağlayan Park, which was widely used as a children's park in the past years, there is a kiosk, sports and play equipment for children, lighting, litter boxes, various urban furniture such as a pergola and statues, an animal shelter (peacocks), and various plan elements. In the recent past some renovations were carried out by the Nicosia Turkish Municipality, but it is not preferred by users as much as it was in the past. In is understood that most of the plants in the park are from past periods, and some of them were cut off due to renovations. At present the park is used for various festivals and exhibitions, and sometimes as a meeting and gathering place by the city dwellers (Figure 13). 

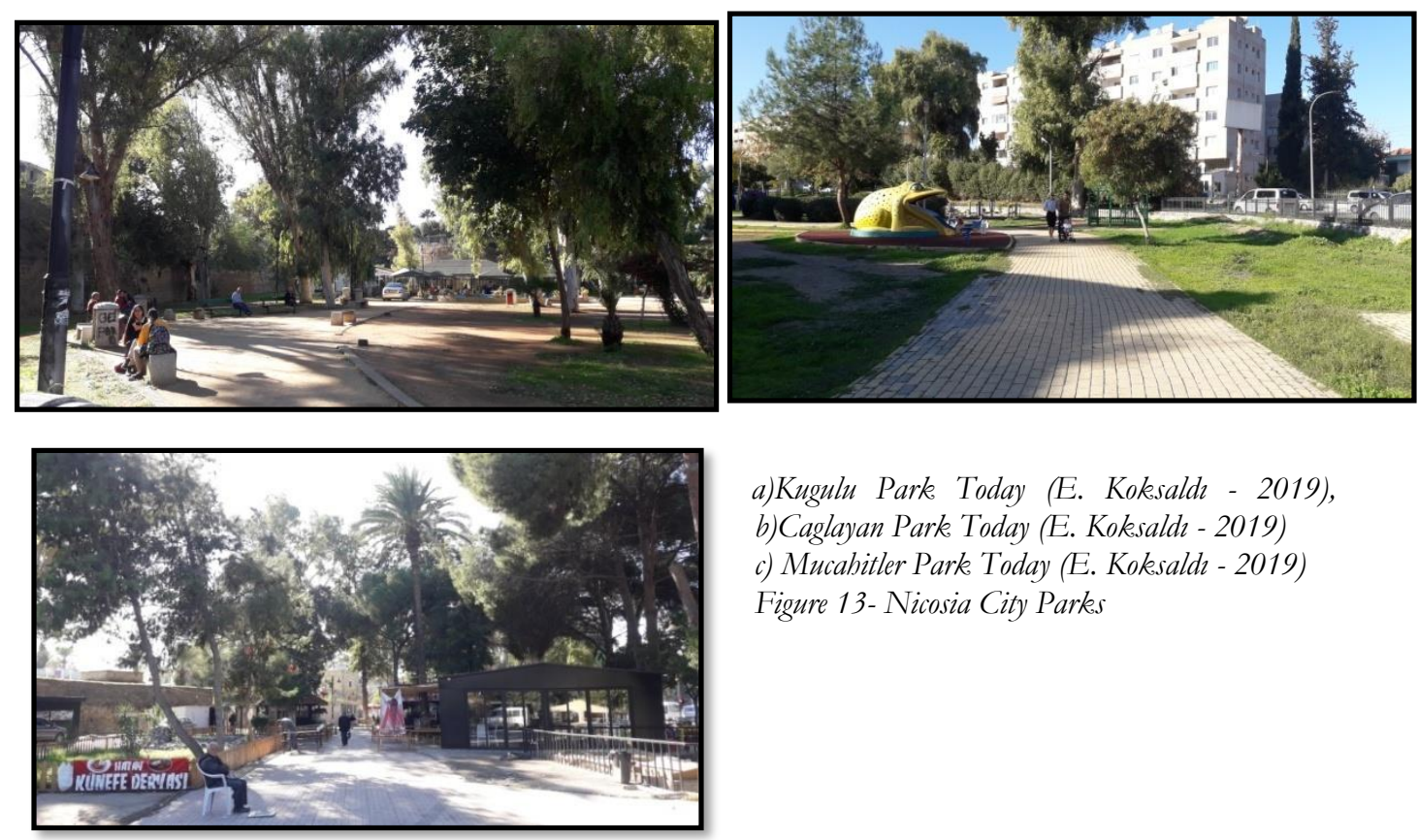

a)Kugulu Park Today (E. Koksaldr - 2019), b) Caglayan Park Today (E. Koksaldo - 2019) c) Mucabitler Park Today (E. Koksaldr - 2019) Figure 13- Nicosia City Parks

It is known that in the historical past of Nicosia there was a sustainable relationship between house-street, street-avenue, and avenue-square, and people used these spaces extensively for their social lives. These spaces, actively used by people, were shaped and developed in accordance with the needs of users. Oktay (2002:265) further suggested that in the central parts of the Cypriot traditional city, the urban spatial pattern reflects a great variety both in terms of functional layout and physical components.

It is understood from research and observations that open and green spaces of the historical urban texture of northern Nicosia suffered significant destruction and deteriorations in the meantime, within the last 50 years in particular. The main reason for this deterioration is the unfavorable physical situations that arose with the division of the historical texture. These unfavorable situations affected the historical texture in general, and harmed the sustainability of the historical texture. As a consequence, the rich landscape in the history of the city could not survive to the present; there is only some green of trees in the yards of several public buildings and in the yards of a few private ones.

At present, the historical urban texture of Nicosia, housing many works of various cultures, is like an open air museum, and struggling to survive against time without adequate protection. At this point, it can further be underlined that within the last two decades, there is also a growing attention for the conservation and revitalization works (mostly funded by UNOPS, UNDP and EU) in order to support the historical texture of the walled city (Bolkaner, 2018:87).

In brief mainly the city dwellers, and all the related institutions need to follow a conscious policy of preservation supported with all the necessary laws and authority in order to ensure that this important cultural heritage of historical texture in the capital of Cyprus 
continues to survive with the landscape that attach meaning to it. The buildings in the historical texture should be given usage again with functions of culture, art, business, entertainment, and accommodation towards tourism; the open public spaces should be redesigned with landscape planning, thus the historical texture should meet nature again giving meaning to the city.

\section{Conclusion}

Historical quarters are cultural heritages belonging to the formation and development processes of cities with their structural, social, economic phases. Such that most great cities have identifiable quarters generating attraction (Montgomery, 2003:293). The residential areas, transportation networks, and open and closed public spaces made up historical urban textures and they can survive with consciousness and competence in preservation, thus conveying the past to the present. However in many countries both developing as well as developed, historic urban quarters are places of decline, characterized by a disproportion of low-income neighbourhoods, decreased economic opportunity and damaged infrastructure and building stock, despite the potential of being places of wealth and opportunity as vibrant historic centres of commerce and culture (Vehbi \& Hoşkara, 2009:716).

Streets and avenues, squares, green spaces with trees and various plants in parks and gardens which make up the communal spaces in historical cities, have been significant elements of historical textures. They brought people into nature, and met the social, physical, and psychological needs in the lives of people. Such that Montgomery (2003:295) also stated that the amount and quality of public space is a factor for the success of the historic textures.

As the capital of the island of Cyprus, Nicosia is a city where the traces of history and cultures of many different civilizations can be found (Misırlısoy \& Günçe, 2016:151). And the walled city of Nicosia became a mosaic of cultures with the rich architectural works of the various periods in the history of the island, and has been the center of the historical texture of the city.

During the Lusignan period, in which the oldest architectural works can still be seen today in the formation of the historical urban texture of Nicosia, the city gained a rich landscape with the churches, monasteries, mansions and wide streets constructed here, and also with the contribution of a branch of the Pedios river running through the city center, large fruit and vegetable gardens, and green spaces. The green spaces of the city are described in detail in the memoirs of travelers who visited Nicosia during this period.

The most important formation during the Venetian period, which was a period of destruction for Cyprus, was the eleven bastion, five gate city walls, still surrounding the city. Landscape during this period existed with the fruit and vegetable gardens and the green in house yards with the contribution of numerous water wells, as described in the memoirs of travelers visiting the city. Nicosia continued its character as a green city during this period too.

The Ottoman period left its mark in the historical city texture by contributing greatly to the development of Nicosia with Turkish architectural works, such as mosques, convents, inns, baths, fountains, and houses. During this period green spaces diminished compared 
to previous ones, landscape mostly survived with various trees and other plants in the yards of buildings, mostly in houses. Travelers visiting Nicosia during these years, talk about the wells in house yards and the rich landscape, in their memoires. In addition, the British period in Cyprus was a period of change and prosperity for Nicosia, which was still the capital city. With the construction work in the historical texture, a different architectural style came out in the city, and the transportation network was re-designed with motor vehicles arriving in the island for the first time during this period. Many travelers visited Cyprus from the beginning of the British period, and they all mentioned Nicosia with admiration in their memoirs. Nicosia, being in an arid area of the island, but having a landscape with many trees, drew attention of these visitors. In a map of the city prepared in 1881 (Kitchener Map), large amount of green spaces and the rich landscape of the city were documented.

With the beginning of the Republic of Cyprus period in the island in 1960, Nicosia showed a fast development with social, commercial, and cultural functions besides its character as the administrative center. Structural renovations began in Nicosia, which became an important transit center in the Middle East, and multi-floor concrete buildings were constructed instead of traditional ones. While this change was contrary to the historical texture of Nicosia, it harmed the city landscape, and caused a diminishing of green spaces. The inter-communal political and armed conflicts that took place in Cyprus after a short time, Nicosia was divided into two in 1964, as Turkish and Greek sectors, and the development of the city came to a standstill. The demographic changes in Nicosia and the social and economic problems in the Turkish part not only damaged the historical texture in the north of the city, but also affected urban landscapes in a negative way in general. However, to meet the public spaces much needed in northern Nicosia, two parks were created for social gatherings and entertainment and a children park in the moat of the northern side of the city walls. These spaces, right outside the historical texture, but in integration with it, helped in the creation of new green spaces.

With the establishment of the Turkish Republic of Northern Cyprus (TRNC) in the north of the island, in 1983, capital city Nicosia began to show a development outside the city walls. Although public institutions and businesses were mostly within the walled city which houses the historical texture, the rapid change in the demographic structure resulted in the historical texture being left without protection, and thus getting destroyed. During this process, landscape both in public and private areas began to disappear. The opportunities that appeared with the new administrative system in the north increased the alternatives to meet the social needs of city dwellers outside the walled city. Thus, the parks inside the walled city and in the moat lost their importance and became dysfunctional.

At present, the historical city texture in Nicosia is like an open-air museum with so many works belonging to various cultures, but is struggling to survive against time due to inadequate measures in preserving it. The rich landscape in the history of the city did not reach the present; the green today is only made up of some trees in the yards of certain public and private buildings.

This highly important historical texture of the cultural heritage in the capital city of Cyprus - a tourism center in the Mediterranean - and its landscape giving life to this texture, has to be protected and preserved by all the stakeholder institutions and mainly by the city dwellers, via a conscious policy of preservation based on the necessary laws and authority. 
Those buildings in the historical texture must be purged of unsuitable usages, and they should be embodied in tourism with functions such as culture, art, business, entertainment, and accommodation. Open public spaces should be re-designed within the scope of a comprehensive landscape planning. Such that the historical texture should be joined with nature just like it was in the past.

\section{References}

Altan, Z. (2006). Gižemli Kıbrıs (2nd Printing). Lefkoşa: Ateş Printing publishing.

Anonymous. (1978). Lefkoşa şehri müze ve eski eserleri. Lefkoşa: Kıbrıs Türk Müzelerini ve Eski Eserleri

Sevenler Derneği publishing.

Anonymous. (1982). Kıbrıs'ta Türk eserleri. Lefkoşa: Kıbrıs Türk Federe Devleti Eğitim, Gençlik, Kültür ve

Spor Bakanlığ1 Eski Eserler ve Müzeler Dairesi Müdürlüğü publishing.

Bağışkan, T. (2005). Kıbrıs'ta Osmanlı - Türk Eserleri. Lefkoşa: Kuzey Kıbrıs Müze Dostları Derneği

publishing.

Balkan, E. A. (1998). Taribsel sürec içerisinde Kusey Kıbrıs Türk Cumburiyetinde

D.A.Ü. Mimarlık Fakültesi publishing.

Bolkaner, M. (2018). Tarihi çevre yenileme ve kentsel tasarm çalşsmalarmm lefkoşa suriçi örneğinde kent kullanuclarn agcsindan arastirlmast. Unpublished Master Thesis, Near East University, Faculty of Architecture, Nicosia, Cyprus.

Cobham, C. D. (2013). Excerpta Cypria. Lefkoşa: Galeri Kültür publishing.

Dağlı, U. U. (1999). Kıbrıs sokaklarnda mimariye yaşama ve çevreye dair. Lefkoşa: Işı1k Kitabevi publishing.

Doratlı, N., Hoşkara, Ş. Ö., \& Faslı, M. (2004). An analytical methodology for revitalization strategies in historic urban quarters: a case study of the Walled City of Nicosia, North Cyprus. Cities, 21, 4, 329348.

Gunnis, R. (1973). Historic Cyprus. Nicosia: Halkin Sesi Ltd publishing.

Gürkan, H. M. (1989). Dünkiü ve bugünkü Lefkoşa (3rd Printing). Lefkoşa: Belediye publishing

Gürkan, H. M. (1996). Kıbrıs taribinden sayfalar (3rd Printing). Lefkoşa: Galeri Kültür publishing.

Gürkan, H. M. (2006). Dünkü ve bugünkiü Lefkoșa (3rd Printing). Lefkoşa: Galeri Kültür publishing.

Hikmetağalar, H. (1996). Eski Lefkoșa'da semtler ve anular. İstanbul: Marifet publishing.

James, P. (2015). Urban sustainability in theory and practice: circles of sustainability. Routledge, Taylor and Francis Group, London and New York.

Lukach, H. C. \& Jardine, D. J. (2007). The Handbook of Cyprus (Translated: A. Çakıroğlu). Lefkoşa: Galeri

Kültür publishing.

Metin, H. (1959). Kıbrıs taribine toplu bir bakış. Lefkoşa: Halkın Sesi Publishing.

Misırlisoy, D., \& Günçe K. (2016). A critical look to the adaptive reuse of traditional urban houses in the Walled City of Nicosia. Journal of Architectural Conservation, 22, 2, 149-166.

Montgomery, J. (2003). Cultural Quarters as Mechanisms for Urban Regeneration. Part 1: Conceptualising Cultural Quarters. Planning, Practice \& Research, 18, 4, 293-306, DOI: $10.1080 / 1561426042000215614$.

Oktay, D. (2002). The quest for urban identity in the changing context of the city: Northern Cyprus. Cities, 19, 4, 261-271.

Oktay, D. (2004). Urban design for sustainability: A study on the Turkish city. The International Journal of Sustainable Development \& World Ecology, 11:1, 24-35, DOI:10.1080/13504500409469808.

Ozaltın, K. (2018). Lefkoşa Mücahitler Parkı 1971. Accessed on 4 December 2019. https://www.facebook.com/photo.php?fbid=409620976158687\&set $=$ a. 142621 532858634\&type $=3$ \&theater adresinden alindı.

Salvator, A. L. (2012). kibris'n baskeenti Levkosia. (Translated: Y. Vur). Lefkoşa: Galeri Kültür publishing.

Severis, R. C. \& Şevketoğlu, M. (2003). Lefkoșa anıtlar ve anllar. Lefkoşa: Kailas Printing publishing.

Soinia K., \& Birkeland I. (2014). Exploring the scientific discourse on cultural sustainability. Geoforum, 51, 213-223.

Tiesdell, S., Oc, T., \& Heath, T. (1996). Revitalizing historic urban qurters. Routledge, New York, USA.

Turkan, Z. (2008). The formation and development of Sarayonu square within the historical city texture of Nicosia. 
Lefkoşa: Işık Kitabevi publishing.

Turkan, Z. (2010). Kıbrıs'ta Türk mimarisi Lefkoşa'da 19. yüzyıl evleri ve tarihi sokak dokusu. C. Alyılmaz, İ. Demirci, İ. Terzioğlu (Ed.), Türk Dünyası Mimarlk ve Şebircilik Kurultayı 2010 / Astana (s. 279-

286). Ankara: Türkiye Belediyeler Birliği publishing.

Turkan, Z. (2016). Turkish architectural works in Cyprus from the Ottoman period to present. The Turkish

Online Journal of Design, Art and Communication. V. 6 I. 4, 479-487. doi: 10.7456/10604100/011.

Turkan, Z. \& Özburak, Ç. (2018). "Selimiye Square" within the historical city texture of Nicosia. Journal of

History Culture and Art Research, Vol.7 No. 2, 430-443. doi:10.7596/taksad.v7i2.1486.

Vehbi, B. O., Hoşkara, Ş. Ö. (2009). A Model for Measuring the Sustainability Level of Historic Urban Quarters. European Planning Studies, 17, 5, 715-739.

Yektaoğlu, V. (2012). Kıbrı'ın başkenti Levkosia. Lefkoşa: Galeri Kültür publishing.

Yıldız, N. (1994). Tarihi çevre. KKTC'de Çevre Sorunlar Semposyumu (17-18 Şubat 1994). Lefkoşa: KTMMOB publishing. 197-206. 